Portland State University

PDXScholar

\title{
Alpine Ice-Core Evidence of a Large Increase in Vanadium and Molybdenum Pollution in Western Europe During the 20th Century
}

\author{
Monica M. Arienzo \\ Desert Research Institute, Reno, NV \\ Michel Legrand \\ Institut des Géosciences de l'Environnement (IGE) \\ Susanne Preunkert \\ Institut des Géosciences de l'Environnement (IGE) \\ Andreas Stohl \\ University of Vienna \\ Nathan Chellman \\ Desert Research Institute, Reno, NV \\ Follow this and additional works at: https://pdxscholar.library.pdx.edu/esm_fac

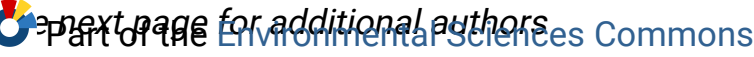 \\ Let us know how access to this document benefits you.
}

\section{Citation Details}

Arienzo, M. M., Legrand, M., Preunkert, S., Stohl, A., Chellman, N., Eckhardt, S., Gleason, K. E., \& McConnell, J. R. (2021). Alpine Ice-Core Evidence of a Large Increase in Vanadium and Molybdenum Pollution in Western Europe During the 20th Century. Journal of Geophysical Research: Atmospheres, 126(4). https://doi.org/10.1029/2020jd033211

This Article is brought to you for free and open access. It has been accepted for inclusion in Environmental Science and Management Faculty Publications and Presentations by an authorized administrator of PDXScholar. Please contact us if we can make this document more accessible: pdxscholar@pdx.edu. 


\section{Authors}

Monica M. Arienzo, Michel Legrand, Susanne Preunkert, Andreas Stohl, Nathan Chellman, Sabine Eckhardt, Kelly E. Gleason, and Joseph R. McConnell 


\section{JGR Atmospheres}

\author{
RESEARCH ARTICLE \\ 10.1029/2020JD033211 \\ Key Points: \\ - Ice core chemistry shows an \\ increasing trend after 1950 with \\ a vanadium peak in 1982 and a \\ molybdenum peak in 1975 \\ - Comparisons to emission estimates \\ from European fossil fuel sources \\ confirm vanadium deposition \\ primarily resulted from oil burning \\ - Ice core data indicate molybdenum \\ emissions from metallurgy were at \\ least as large as emissions from coal \\ burning in Europe
}

Supporting Information:

- Supporting Information S1

Correspondence to:

M. M. Arienzo,

marienzo@dri.edu

Citation:

Arienzo, M. M., Legrand, M., Preunkert, S., Stohl, A., Chellman, N., Eckhardt, S., et al. (2021). Alpine ice-core evidence of a large increase in vanadium and molybdenum pollution in Western Europe during the 20th century. Journal of Geophysical Research: Atmospheres, 126, e2020JD033211. https://doi. org/10.1029/2020JD033211

Received 8 JUN 2020

Accepted 28 JAN 2021

Author Contributions:

Conceptualization: M. M. Arienzo, M. Legrand, S. Preunkert, J. R. McConnell, A. Stohl

Formal analysis: M. M. Arienzo, M. Legrand, J. R. McConnell, A. Stohl, N. Chellman, S. Eckhardt, K. E. Gleason Investigation: M. M. Arienzo, M. Legrand, S. Preunkert

Methodology: M. M. Arienzo, M. Legrand, J. R. McConnell, A. Stohl Resources: S. Preunkert, J. R. McConnell

Supervision: M. Legrand

Writing - original draft: M. M.

Arienzo, M. Legrand

Writing - review \& editing: M. M.

Arienzo, M. Legrand, S. Preunkert, J. R. McConnell, A. Stohl, N. Chellman, S. Eckhardt, K. E. Gleason

\section{Alpine Ice-Core Evidence of a Large Increase in Vanadium and Molybdenum Pollution in Western Europe During the 20th Century}

\author{
Monica M. Arienzo ${ }^{1}\left(\mathbb{D}\right.$, Michel Legrand $^{2,3}$ (D), Susanne Preunkert ${ }^{2}\left(\mathbb{D}\right.$, Andreas Stohl $^{4}$ (D),

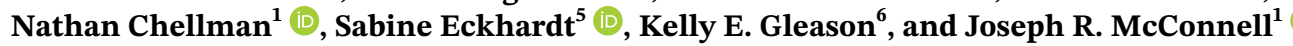 \\ ${ }^{1}$ Division of Hydrologic Sciences, Desert Research Institute, Reno, NV, USA, ${ }^{2}$ Université Grenoble Alpes, CNRS, \\ Institut des Géosciences de l'Environnement (IGE), Grenoble, France, ${ }^{3}$ LISA (Laboratoire Interuniversitaire des \\ Systèmes Atmosphériques), UMR CNRS 7583, Université Paris-Est-Créteil, Université de Paris, Institut Pierre Simon \\ Laplace (IPSL), Créteil, France, ${ }^{4}$ Department of Meteorology and Geophysics, University of Vienna, Vienna, Austria, \\ ${ }^{5}$ Department of Atmospheric and Climate Research, NILU - Norwegian Institute for Air Research, Kjeller, Norway, \\ ${ }^{6}$ Department of Environmental Science and Management, Portland State University, Portland, OR, USA
}

Abstract Pollutants emitted by industrial processes are deposited across the landscape. Ice core records from mid-latitude glaciers located close to emission sources document the history of local-toregional pollution since preindustrial times. Such records underpin attribution of pollutants to specific emission sources critical to developing abatement policies. Previous ice core studies from the Alps document the overall magnitude and timing of pollution related to nitrogen and sulfur-derived species, as well as a few metals including lead. Here, we used subannually resolved measurements of vanadium (V) and molybdenum (Mo) in two ice cores from Col du Dome (French Alps), as well as atmospheric transport and deposition modeling, to investigate sources of pollution in the free European troposphere. The noncrustal $\mathrm{V}$ and $\mathrm{Mo}$ (ncV, ncMo) components were calculated by subtracting the crustal component from the total concentration. These ice core results showed a 32 -fold increase in $\mathrm{ncV}$ and a 69 -fold increase in ncMo from the preindustrial era (pre-1860) to the industrial concentration peaks. Anthropogenic $\mathrm{V}$ and Mo emissions in Europe were estimated using emission factors from oil and coal consumption and atmospheric transport and deposition modeling. When comparing ice core data to estimated anthropogenic $\mathrm{V}$ and Mo emissions in Europe, $\mathrm{V}$ was found to be sourced primarily from oil combustion emissions. Conversely, coal and oil combustion estimated emissions did not agree with the measured ice core Mo concentrations, suggesting that other anthropogenic Mo sources dominated coal-burning emissions, particularly after the 1950s. Noncoal-burning sources of Mo may include metallurgy although emission factors are poorly known.

Plain Language Summary Industrial activities release pollutants that are transported and deposited across the landscape. Such pollutants include metals that can impact wildlife, the environment, and human health. Vanadium and molybdenum metals are essential elements for life but have possible harmful effects at high concentrations. Historical anthropogenic emissions of these two metals remain uncertain. Here, we analyzed vanadium and molybdenum in two ice cores extracted from Col du Dome, located in the French Alps. Results showed an increase in pollution-sourced vanadium and molybdenum from the preindustrial era to the 1970s and 1980s. Anthropogenic vanadium and molybdenum deposition at the core site were estimated using previously published emission factors and consumption of fossil fuels combined with atmospheric transport and deposition modeling. When comparing ice core vanadium measurements to estimated deposition from anthropogenic emissions from oil combustion, good agreement was observed-supporting that vanadium pollution in the ice was sourced primarily from oil combustion in Europe. Conversely, prior thinking was that molybdenum emissions were dominated by coal combustion, but estimated deposition from fossil fuel emissions did not agree with the ice core data. We propose instead that the processing of molybdenum ore was an additional source of molybdenum. 


\section{Introduction}

Pollutants from anthropogenic activities are emitted to the atmosphere and deposited across various spatial scales, depending on their lifetimes in the atmosphere. Anthropogenic sulfate (Fagerli et al., 2007; Preunkert et al., 2001; Schwikowski et al., 1999) and nitrate (Doscher et al., 1995; Preunkert et al., 2003; Schwikowski, 2006; Schwikowski et al., 1999) have been well studied in ice cores and shown to have global environmental impacts including acid rain and photochemical ozone pollution in the lower troposphere. Metal pollutants are not as well studied, but have had far-reaching effects (Eichler et al., 2015; McConnell \& Edwards, 2008; McConnell et al., 2018; Vallelonga et al., 2004). Of particular interest are transition metals, such as vanadium (V) and molybdenum (Mo) that are essential elements for life (Gustafssona, 2019; Schlesinger et al., 2017; Smedley \& Kinniburgh, 2017). V and Mo have been shown to have harmful effects at high concentrations (Agency for Toxic Substances and Disease Registry, 2012; Smedley \& Kinniburgh, 2017). Exposure studies demonstrate V may cause a number of negative health effects in mammals including reproductive and developmental issues (Domingo, 1994). Such concerns motivated the state of California to lower V drinking water regulations (Spath, 2000). Several studies have also been conducted to assess Mo health effects and demonstrate negative health effects which vary depending on the exposure type and the chemical state (Smedley \& Kinniburgh, 2017; World Health Organization, 2003).

Global anthropogenic sources of V and Mo are thought to be dominated by fossil fuel combustion (Pacyna \& Pacyna, 2001; Schlesinger et al., 2017). According to previous estimates, V is sourced primarily from oil combustion, and Mo is sourced primarily from coal combustion and to a lesser extent oil combustion (Gustafssona, 2019; Pacyna \& Pacyna, 2001; Schlesinger et al., 2017). If correct, these metals may be useful for identifying the contribution of fossil fuel combustion to the budget of other pollutants. $\mathrm{V}$ and Mo anthropogenic emissions have been estimated using observations for individual European countries in 1979 Common Era (CE) (Pacyna, 1984; Pacyna et al., 1984) and globally for 1983 and 1995 CE (Nriagu \& Pacyna, 1988; Pacyna \& Pacyna, 2001), although no long-term, continuous atmospheric observations of $\mathrm{V}$ and Mo are available. This is in contrast to lead, mercury, and cadmium for which past emissions have been estimated using emission observations every 5-10 years from 1955 to 2005 CE for individual European countries, and atmospheric measurements of these pollutants are available since the 1990s (Pacyna et al., 2009). The lack of continuous, long-term Mo and V observational data hinders assessment of sources. Records of such pollutants provide an important context for current atmospheric observations and future emission predictions.

Measurement of elements of interest from a single archive located near pollution sources allows for accurate characterization of pollutant emissions through time to reduce uncertainties in source apportionment (Legrand et al., 2020). Ice cores collected from the summit of the Alps are excellent archives of historical changes in European pollution provided the ice cores can be dated accurately (Preunkert et al., 2001, 2003; Schwikowski et al., 1999). Previous alpine ice core studies from the Alps dedicated to V (Barbante et al., 2002) and Mo (Barbante et al., 2004; Van de Velde et al., 1999) are discontinuous, not seasonally resolved, and only extend back to the 1960s for V. The V ice core record (Barbante et al., 2002) does not extend far enough back in time to confirm the dominance of anthropogenic V sourced from oil combustion. Another study from Col du Dome (CDD) in the French Alps near the Mont Blanc summit reported Mo concentrations increased by a factor of 15 from the mid-1900s to 1990 CE (Van de Velde et al., 1999). A similar Mo increase was also observed at Colle Gnifetti, located at the Monte Rosa site in the Italian-Swiss region (Barbante et al., 2004). This observed Mo increase after 1950 CE conflicts with the consensus view that anthropogenic Mo emissions are dominated in Europe by coal combustion, as a significant amount of coal consumption in Europe began earlier in the 1930s (Mitchell, 1978).

Here, we present a seasonally resolved record of V and Mo deposition from 1890 to 2000 CE from the CDD glacier located near the Mont Blanc summit. Our goals were to better understand (1) the relative contribution of natural and anthropogenic sources of $\mathrm{V}$ and $\mathrm{Mo}$; and (2) to compare the ice core findings to anthropogenic emission estimates for $\mathrm{V}$ and Mo with state-of-the-art FLEXPART atmospheric transport and deposition modeling. We chose these two elements because previous ice core records have not been conclusively compared to estimated emissions in Europe. 

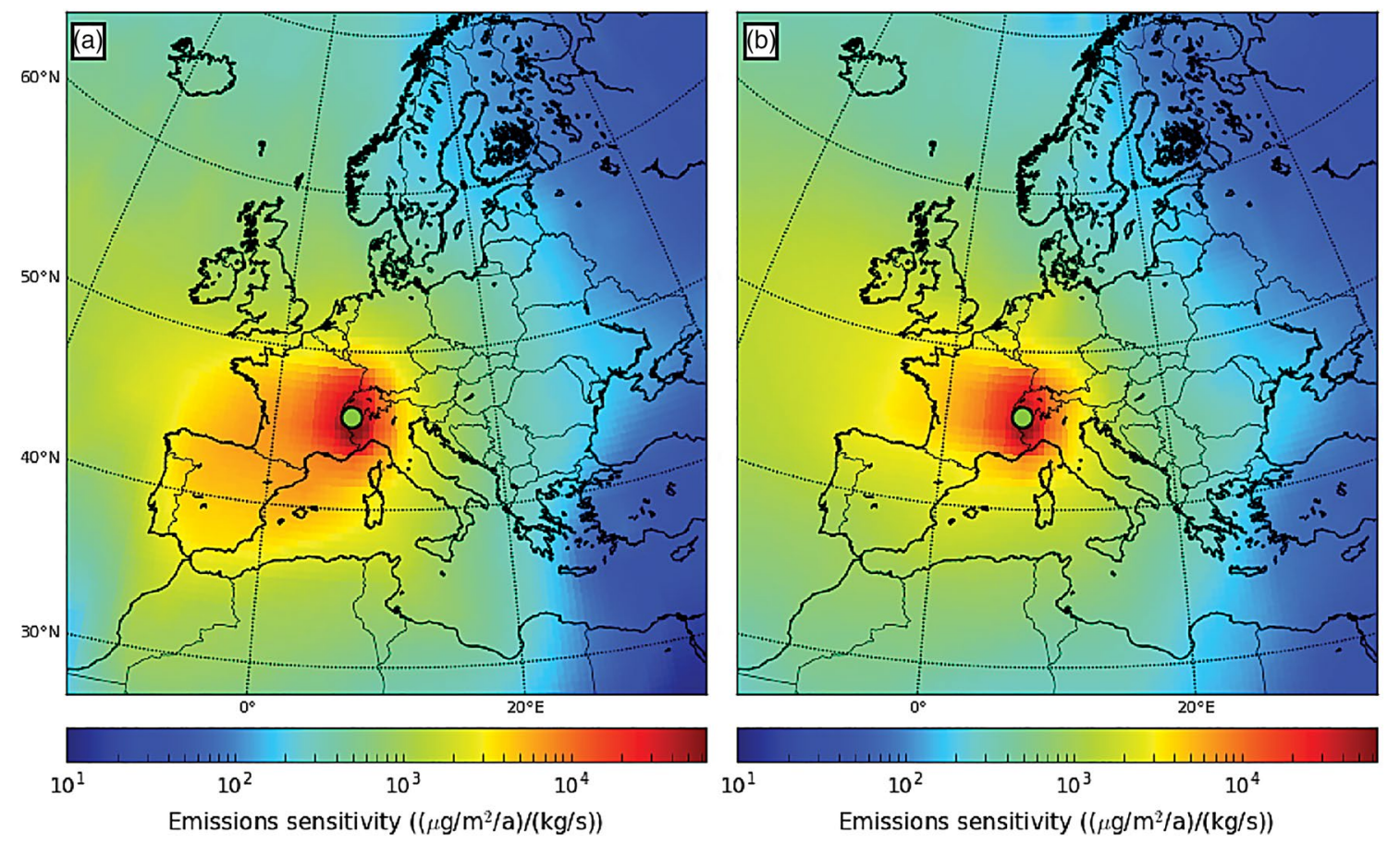

Figure 1. Emissions sensitivities at the CDD ice-core site (green dot) based on FLEXPART model simulations of sulfate aerosol transport and deposition for: (a) summer and (b) winter. In the winter (panel B), an enhanced sensitivity to emissions from northwestern Germany and the United Kingdom versus Spain is observed. CDD, Col du Dome.

\section{Methods}

\subsection{Ice Core Samples}

To develop an accurately dated record of 20th century V and Mo pollution in western Europe, we used a continuous ice core analytical system to measure elements from two ice cores previously collected in the French Alps at CDD (Figure 1) (Preunkert \& Legrand, 2013; Preunkert et al., 2000). These were the $126 \mathrm{~m}$ $\mathrm{C} 10$ core drilled in $1994\left(45.83^{\circ} \mathrm{N}, 6.85^{\circ} \mathrm{E}, 4,350 \mathrm{~m}\right)$ and the $140 \mathrm{~m}$ CDM core drilled less than $20 \mathrm{~m}$ away in 2012.

\subsection{Continuous Chemical Analyses}

Longitudinal samples $(\sim 3.3 \mathrm{~cm} \times \sim 3.3 \mathrm{~cm})$ were cut from the C10 and CDM ice cores and analyzed in 2017 using the Desert Research Institute continuous ice core analytical system (McConnell et al., 2002). The longitudinal samples were melted continuously from bottom to top using an ultra-clean, ceramic melter head with melt water pumped to instruments for near-real-time measurements. Similar to previous studies (McConnell et al., 2002, 2018), meltwater from the center $10 \%$ of the sample cross section was immediately acidified inline to $1 \%$ nitric acid, and the sample stream was introduced to two Thermo-Finnigan Element2 (Thermo Scientific) high-resolution inductively coupled plasma mass spectrometers (HR-ICPMS) approximately four and a half minutes after melting. One HR-ICP-MS measured ${ }^{95} \mathrm{Mo}$ and ${ }^{140} \mathrm{Cerium}$ $\left({ }^{140} \mathrm{Ce}\right)$ elements in low-slit resolution $(\mathrm{M} / \Delta \mathrm{M}=300)$, while ${ }^{51} \mathrm{~V}$ was measured in medium-slit resolution $(\mathrm{M} / \Delta \mathrm{M}=4,000)$ on the second HR-ICP-MS. Ce was used here to estimate the crustal contribution of $\mathrm{V}$ and Mo (see Section 2.4). Overall, mixing within the flow system resulted in an estimated effective depth resolution of $\sim 2 \mathrm{~cm}$. The detection limits, defined as three times the standard deviation of the blank, were $0.0006 \mathrm{ng} \mathrm{g}^{-1}$ for V, $0.0001 \mathrm{ng} \mathrm{g}^{-1}$ for Mo, and $0.0003 \mathrm{ng} \mathrm{g}^{-1}$ for Ce.

We compared our measurements to previously published V (Barbante et al., 2002) and Mo (Van de Velde, 1999; Van de Velde et al., 1999) concentrations obtained from a core collected near the CDD site (Table S1, Figure S1). Note that in these previous studies, a subset of the snow and ice layers (around 10\%-15\%) 

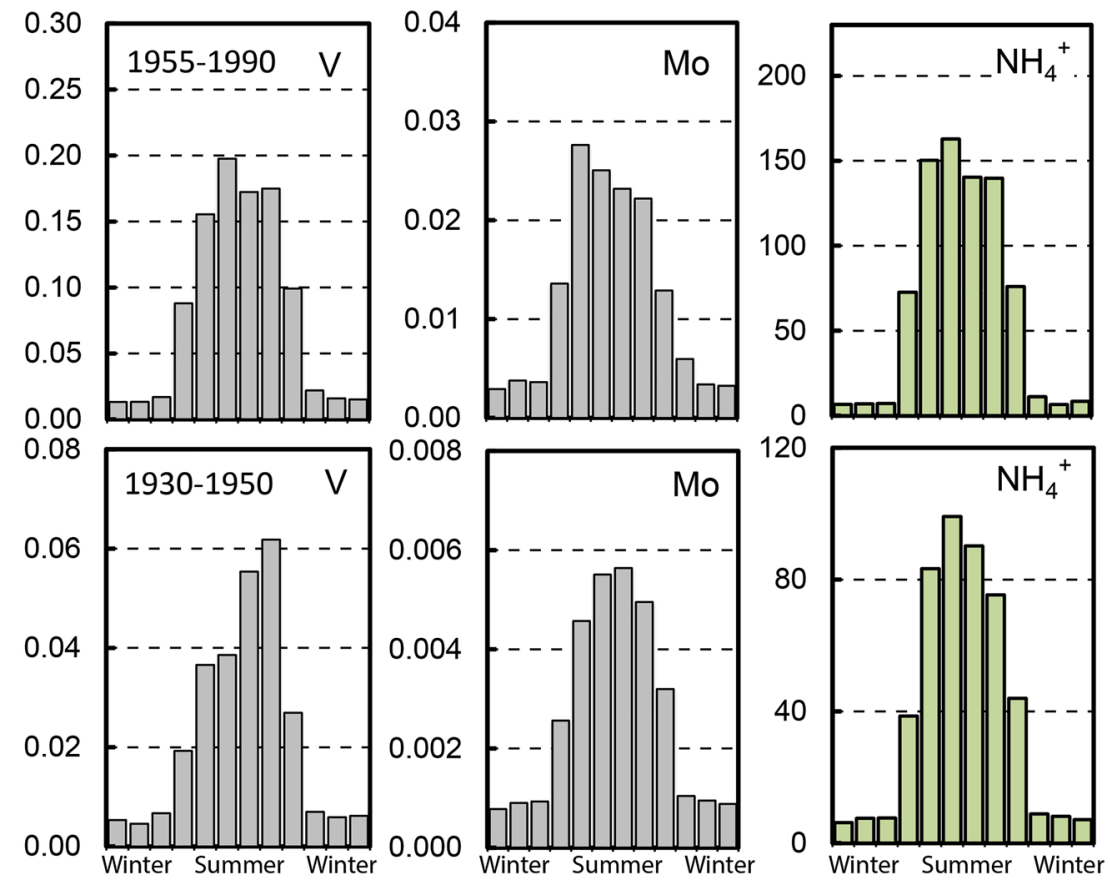

Figure 2. Average seasonal variations of $\mathrm{V}$ and Mo concentration in gray, and ammonium $\left(\mathrm{NH}_{4}^{+}\right)$in $g r e e n(f r o m$ Preunkert et al., 2000) for 1955 to $1990 \mathrm{CE}$ (top row) and 1930 to $1950 \mathrm{CE}$ (bottom row). All concentrations are in ng g-1. Ammonium was used to determine seasonality, as described in Section 2.3. CE, Common Era

were analyzed, and no systematic seasonal separation was conducted. For comparison to our continuous measurements, we estimated mean as well as averaged half-year winter and summer value concentrations for the common time period, with winter values determined by averaging the lowest one-third of the concentrations measured each year as previous work demonstrates this represents the winter seasonal deposition (Preunkert et al., 2001). General agreement was found between the new and previously reported measurements (Table S1).

\subsection{Dating the Ice Core Records}

We exploited seasonal resolution of the CDD records made possible by the net high snow accumulation (0.50- 2.40 m water equivalent per year [mwe $\mathrm{yr}^{-1}$ ] [Preunkert et al., 2000]). Source regions and transport of aerosols in summer versus winter are very different in the Alps because strong summertime convection results in vigorous upward transport of pollutants emitted within the boundary layer to the high-altitude CDD site (Preunkert et al., 2001). The result is much higher concentrations of most impurities in the summer snow layers compared to winter snow layers, in particular for ammonium (Figure 2). This seasonal resolution allowed for dating by annual-layer counting, as has been described in Preunkert et al. (2000) and extended back to $1890 \mathrm{CE}$ by Legrand et al. (2018). We obtained a seasonally resolved (summer, winter) ice core CDD record from 1891 through $1985 \mathrm{CE}$ in the C10 core and from 1979 to $1999 \mathrm{CE}$ in the CDM core (Legrand et al., 2018). Winter layers generally thin with depth relative to summer layers because of a lack of preservation of blowing winter snow upstream of the CDD drilling site. We were able to identify winter layers for annual layer counting back to $1890 \mathrm{CE}$. However, from 1891 to $1929 \mathrm{CE}$ many of the winter ammonium minima were too thin to determine reliably winter concentrations of $\mathrm{V}$ and Mo. Therefore, for only six winter layers V and Mo concentrations were calculated (1891, 1903, 1908, 1910, 1916, and 1923 CE, Figure 3). After $1929 \mathrm{CE}$, winter layers were thicker, and V and Mo concentrations were more consistently calculated. Prior to $1890 \mathrm{CE}$, no winter snow was preserved, but the age from 125 to $122 \mathrm{~m}$ depth of the C10 core was estimated by Legrand et al. (2020) to be 1835-1860 CE (possibly 1640-1840 CE) (i.e., beyond the onset of the preindustrial period). We used V, Mo, and Ce concentrations from 125 to $122 \mathrm{~m}$ depth of the C10 core to evaluate the preindustrial (background) concentrations. 

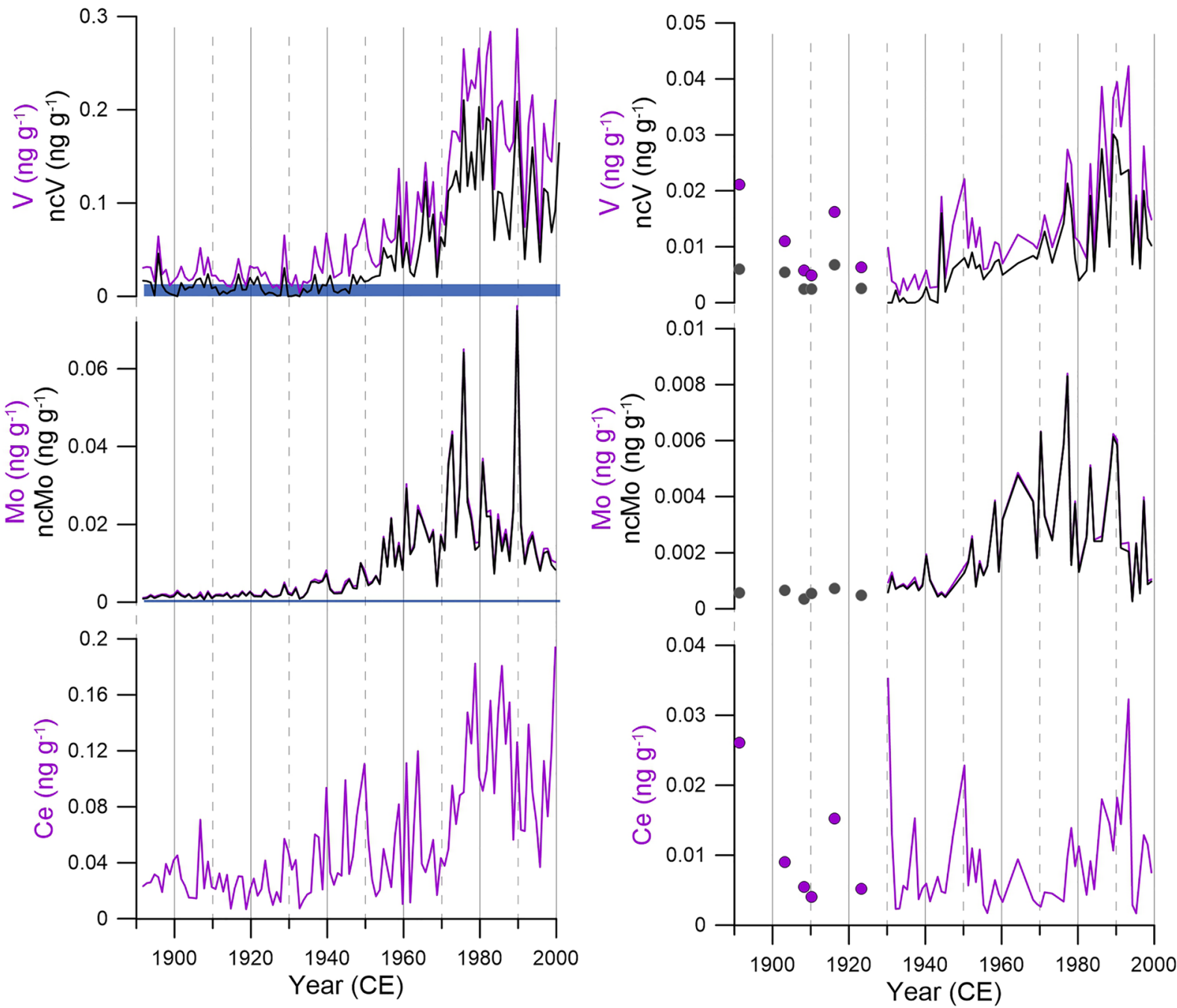

Figure 3. CDD chemistry results. Left panel: CDD summer results for V (top), Mo (middle) and Ce (bottom, scaled for recovery). Purple line represents summer annual mean concentrations. The black line represents the noncrustal (nc) summer annual mean concentrations. Blue horizontal bar for ncV and ncMo represent average preindustrial summer concentration ( \pm 1 sigma, see Table 1). Right panel: Ice core winter annual mean (purple line) and noncrustal winter annual mean (black line) are shown. Prior to $1930 \mathrm{CE}$, winter annual mean (purple circle) and noncrustal winter annual mean (black circle) are also shown. CDD, Col du Dome; CE, Common Era.

The overlapping sections of C10 and CDM cores (from 1979 to $1985 \mathrm{CE}$ ) showed very good agreement. For $\mathrm{V}$, summer average concentrations were $0.19 \pm 0.06 \mathrm{ng} \mathrm{g}^{-1}$ in CDM ice and $0.26 \pm 0.13 \mathrm{ng} \mathrm{g}^{-1}$ in C10 ice. For Mo, the summer average for the overlapping period was $0.018 \pm 0.007 \mathrm{ng} \mathrm{g}^{-1}$ in CDM ice compared to $0.021 \pm 0.008 \mathrm{ng} \mathrm{g}^{-1}$ in $\mathrm{C} 10$ ice. For winter, concentrations were also close in the two ice-cores. For V, the average winter concentration was $0.019 \pm 0.011 \mathrm{ng} \mathrm{g}^{-1}$ in CDM ice compared to $0.022 \pm 0.011 \mathrm{ng} \mathrm{g}^{-1}$ in C10 ice for $\mathrm{V}$ and $0.0030 \pm 0.0013 \mathrm{ng} \mathrm{g}^{-1}$ in CDM ice compared to $0.0033 \pm 0.0012 \mathrm{ng} \mathrm{g}^{-1}$ in C10 ice for winter Mo.

\subsection{Elemental Composition}

Measurement of total elemental concentrations may be influenced by acidification times in continuous analyses because more recalcitrant elements such as rare-earth elements will remain in the particle phase longer than others and may not be fully recovered in continuous HR-ICP-MS measurements (Arienzo et al., 2019; Uglietti et al., 2014). Elements associated with pollution sources have been shown to be fully $(100 \%)$ recovered as pollutants are thought to be coatings on particles and therefore easily dissolved (Arienzo et al., 2019; McConnell et al., 2018). For example, in a recent analysis of elemental recovery in Greenland 
ice core samples, recovery during continuous measurements of $\mathrm{Ce}$ and lead was found to be $\sim 60 \%$ and $100 \%$, respectively (McConnell et al., 2018). We have assumed a similar Ce recovery for CDD measurements as dust particles reaching Greenland and the Alps are subject to long-range transport and the dust particles are thought to be similar in size. No scaling was implemented for V and Mo because they were assumed to be sourced primarily from pollution at this site during the 20th century.

To assess V and Mo from anthropogenic sources as well as other noncrustal (nc) natural sources, nc components were calculated by subtracting the crustal component from the total $\mathrm{V}$ and Mo concentration measured by HR-ICP-MS. As conducted in previous ice core studies from Greenland and several high-elevated mid-latitude glaciers (Eichler et al. 2015, 2017; McConnell et al., 2018), we used Ce to estimate the crustal contribution of V and Mo. From CDD ice we observe a high correlation and a null $y$-intercept between Ce concentration and aluminum $\left(R^{2}=0.91\right)$, lanthanum $\left(R^{2}=0.95\right)$, and samarium $\left(R^{2}=0.93\right)$, which supports the use of $\mathrm{Ce}$ as crustal reference element at this site. We acknowledge that there are anthropogenic sources of Ce, including industrial sources (abrasives, catalysts, additives, and alloys) and from nanotechnology (Gogos et al., 2020). While these sources may contribute to the local atmospheric Ce budget, these sources are minor when compared to crustal aerosol sources to the polar and high elevation sites.

We calculated the crustal component from the $\mathrm{V}$ to Ce relationship (with Ce scaled for recovery) in the preindustrial summer ice (Figure S2). The preindustrial summer data were used for this calculation, as this period was free of significant anthropogenic pollution and captured the natural variation in dust at the ice core site. From the linear relationship ( $[\mathrm{V}]=0.6[\mathrm{Ce}]+0.008, r^{2}=0.6, n=234$ ), a crustal V/Ce ratio of 0.6 was calculated (Figure S2). The crustal component was then calculated as the measured Ce concentration (scaled for recovery) multiplied by the calculated V/Ce ratio (0.6), based on the assumption that all Ce was derived from crustal dust. The crustal component was subtracted from the total $\mathrm{V}$ concentration to calculate the $\mathrm{ncV}$ value. During the 20th century, the $\mathrm{ncV}$ and ncMo fraction is primarily sourced from pollution $\mathrm{V}$ and Mo, with minor contributions from other noncrustal sources such as volcanic emissions and fire. We note that the $\mathrm{V} / \mathrm{Ce}$ ratio of 0.6 from the ice core was within the range of $0.3-4.23$ from various rock types (Bowen, 1966). A similar analysis was conducted for Mo, with a linear relationship ([Mo] $=0.01$ [Ce $]+0.0004, r^{2}=0.5, n=232$ ) and a crustal Mo/Ce ratio of 0.01 (Figure S2). This also was within the range of 0.008-0.027 for various rock types (Bowen, 1966). We emphasize that knowledge of the degree of recovery of Ce analysis is important for comparing the crustal ratios derived from Figure S2 and those in various rock types, but not in estimating the crustal contribution for the approach used here.

The annual ncV and ncMo summer values were then smoothed using a first component of single-spectra analysis (SSA) with a 7-year window from 1890 to $2000 \mathrm{CE}$. This smoothing window was chosen to smooth the interannual variation in vertical transport at this site, similar to previous CDD studies (Preunkert et al., 2001, 2003).

\subsection{FLEXPART Model and Fossil Fuel Statistics}

We used the Lagrangian particle dispersion model FLEXPART (Stohl et al., 2005) to investigate emission sensitivities at the CDD ice core site by running the model backward in time for wet and dry deposition (Eckhardt et al., 2017), similar to the approach used in McConnell et al. (2018) and Legrand et al. (2020). FLEXPART simulations were conducted for sulfate (Figure 1), small dust (1 $\mu \mathrm{m}$ diameter), and large dust ( $5 \mu \mathrm{m}$ diameter) aerosols (Figures S3 and S4). The meteorological input to FLEXPART was the coupled climate reanalysis for the 20th century (CERA-20C) (Laloyaux et al., 2018) from the European Center for Medium Range Weather Forecasts (ECMWF) at a resolution of $2^{\circ} \times 2^{\circ}$ for every 6 hours. The simulation was run in backward mode at monthly intervals from 1901 through $1999 \mathrm{CE}$; particles were traced for 30 days.

FLEXPART model simulations of atmospheric transport and deposition were used to identify summer and winter source regions for pollutants deposited at the CDD site (Figure 1). FLEXPART model simulations of atmospheric transport and deposition demonstrated that the CDD ice core site was most sensitive to emissions from France, Italy, Spain, Switzerland, and Germany during both summer and winter (Table S2). To assess sources of fossil fuel pollutants from these five countries, annual coal and petroleum consumption for France, Italy, Spain, Switzerland, and Germany were estimated from 1890 to 2015 CE (Figure S5). Prior to $1975 \mathrm{CE}$, consumption was calculated from production, import, and export estimates for each country, 
Table 1

Ice Core Vanadium (V), Molybdenum (Mo), Noncrustal V(ncV) And Noncrustal Mo (ncMo) Concentrations Averaged at Four Different Time Periods: Preindustrial, 1890s, Concentration Peak (1977-1982 Common Era for ncV; 1970-1975 Common Era for ncMo), and End of the 20th Century

\begin{tabular}{|c|c|c|c|c|c|c|}
\hline Period & $\mathrm{V}\left(\mathrm{ng} \mathrm{g}^{-1}\right)$ & Mo $\left(\operatorname{ng~g}^{-1}\right)$ & $\mathrm{ncV}\left(\mathrm{ng} \mathrm{g}^{-1}\right)$ & $\Delta$ relative to $\mathrm{PI}$ & ncMo $\left(\mathrm{ng} \mathrm{g}^{-1}\right)$ & $\Delta$ relative to $\mathrm{PI}$ \\
\hline PI & $0.026 \pm 0.020$ & $0.0008 \pm 0.0005$ & $0.005 \pm 0.008$ & - & $0.0004 \pm 0.0002$ & - \\
\hline 1890-1895 & $0.035 \pm 0.018$ & $0.0015 \pm 0.0003$ & $0.019 \pm 0.017$ & 4 & $0.0012 \pm 0.0003$ & 3 \\
\hline Peak & $0.231 \pm 0.034$ & $0.028 \pm 0.0127$ & $0.160 \pm 0.04$ & 32 & $0.028 \pm 0.0125$ & 69 \\
\hline End of 20 th century & $0.150 \pm 0.058$ & $0.011 \pm 0.0023$ & $0.086 \pm 0.033$ & 17 & $0.010 \pm 0.0024$ & 26 \\
\hline
\end{tabular}

Delta $(\Delta)$ relative to PI shows the factor increase relative to PI.

with consumption equal to production plus imports minus exports (Mitchell, 1978). For more recent years (1976-2000 CE), we used consumption data from British Petroleum (British Petroleum, 2020). Annual coal and petroleum consumption for the five countries (Figure S5) were then weighted by the relative emission sensitivity of the CDD site to emissions in that country by season (summer or winter) from the FLEXPART modeled sulfate (Table S2) and summed.

\section{Results and Discussion}

The ice core pollution trends were better documented in the summer deposits throughout our record. We focus on the summer trends in the following sections and only briefly discuss the winter trends as winter deposits were less prevalent because of wind erosion of winter season snow. The summer and winter annual V, Mo, and Ce concentrations are reported in Figure 3.

\subsection{Continental Dust}

The continuous, high-depth-resolution measurements in the CDD ice cores showed that summer concentrations of impurities from continental dust, as well as pollutants, varied substantially from 1890 to 2000 CE (yearly summer mean in Figure 3 and the $2 \mathrm{~cm}$ record in Figure S6). Summer concentrations of Ce showed an increase from 1970 to $1980 \mathrm{CE}$ (Figure 3) likely because of enhanced dust export from the Sahara/Sahel region to the Alps, as previously discussed in several studies (Bohleber et al., 2018; De Angelis \& Gaudichet, 1991; Preunkert \& Legrand, 2013; Sodemann et al., 2006). Winter Ce concentrations were lower relative to summer concentrations and did not show a systematic long-term change as observed in the summer (Figure 3).

\subsection{Anthropogenic $\mathrm{V}$ and $M o$}

To separate variations in $\mathrm{V}$ and Mo concentrations sourced from anthropogenic emissions from variations in $\mathrm{V}$ and Mo concentrations sourced from dust, we subtracted the crustal contributions of V and Mo. The results are shown as $\mathrm{ncV}$ and $\mathrm{ncMo}$ and represent the fraction primarily sourced from pollution. As seen in Figure 3, the crustal contribution was minor for Mo except during preindustrial (PI). In contrast, for V, the crustal contribution was greater with up to a $30 \%$ contribution in the late 1970s (Figure 3).

Average PI summer ice (C10 ice core from 125 and $122 \mathrm{~m}$ depth, see section 2.3) concentration for ncV was $0.005 \pm 0.008 \mathrm{ng} \mathrm{g}^{-1}$ and $0.0004 \pm 0.0003 \mathrm{ng} \mathrm{g}^{-1}$ for ncMo (Table 1 ). These PI values reflect primarily natural sources of $\mathrm{V}$ and Mo. The 12 times higher PI concentration of ncV compared to ncMo was consistent with estimates of global natural emissions of noncrustal V (12 ktonnes $\mathrm{yr}^{-1}$ of which $5.6 \mathrm{ktonnes} \mathrm{yr}^{-1}$ were from volcanoes and 1.8 ktonnes $\mathrm{yr}^{-1}$ were from forest fires) and noncrustal Mo (1.7 ktonnes $\mathrm{yr}^{-1}$ of which

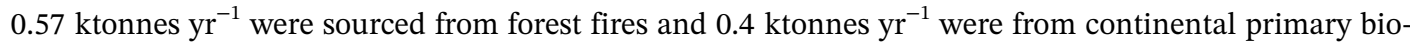
genic emissions) (Nriagu, 1989).

By the 1890s, summer ncV values were slightly higher than preindustrial values with an average concentration of $\sim 0.02 \mathrm{ng} \mathrm{g}^{-1} \mathrm{ncV}$. Concentrations remained relatively low and unchanged until the 1950s, when $\mathrm{ncV}$ values began to increase to a peak from 1977 to $1982 \mathrm{CE}$ of $\sim 0.16 \mathrm{ng} \mathrm{g}^{-1}$, a 32-fold increase from 
preindustrial ncV values (Figure 3, Table 1). After the peak in $1982 \mathrm{CE}, \mathrm{ncV}$ nearly halved to a mean value of $0.09 \mathrm{ng} \mathrm{g}^{-1}$ by the end of the 20th century (Figure 3, Table 1), a concentration similar to that observed in the ice from the early 1970 s.

A different trend was observed for summer ncMo concentrations. By the $1890 \mathrm{~s}$, ncMo concentrations increased to an average value of $0.001 \mathrm{ng} \mathrm{g}^{-1}$ (Figure 3), 3 times above the preindustrial value. The ncMo values continued to increase during the early 20th century, with an increase to $0.004 \mathrm{ng} \mathrm{g}^{-1}$ by $1945 \mathrm{CE}$. After $1950 \mathrm{CE}$, ncMo concentrations increased at a faster rate than ncV. Peak ncMo concentration was $0.028 \mathrm{ng}$ $\mathrm{g}^{-1}$ from 1970 to $1975 \mathrm{CE}$, a 69-fold increase from preindustrial concentrations. This was followed by a decline to a mean value of $0.010 \mathrm{ng} \mathrm{g}^{-1}$ by the end of the 20th century, similar to concentrations observed in the 1950s. Note that the relative decrease at the end of the 20th century was greater for ncMo than for $\mathrm{ncV}$ (Figure 3).

Winter concentrations of $\mathrm{ncV}$ and ncMo were approximately $1 / 5$ th the summer values (Figures 2 and 3 ), similar to the very large seasonal contrasts observed at the CDD ice core site for other chemical species (Preunkert et al., 2000, 2001, 2003). FLEXPART simulations also showed seasonal differences in source areas for CDD, with greater sensitivity to regional pollution sources during the summer-in particular, to emissions from France and Spain. In the winter, an enhanced sensitivity to long-range emissions, particularly from the United Kingdom versus Spain, is observed (Figure 1). We note, however, that FLEXPART's convection scheme produces enhanced vertical transport in summer, but the Alpine topography is not well resolved in the meteorological data driving the simulations. Convection related to mountain circulation regimes (e.g., valley winds, slope winds, or enhanced convection over mountaintops) would thus be poorly captured by the model. Regardless, these seasonal differences agree with previous work at CDD (Fagerli et al., 2007).

The winter ncV values exhibited low values until the 1960s when ncV values began to increase (Figure 3). Winter ncV values peaked in the mid-1980s, followed by a decline. Winter ncMo concentrations began to increase in the mid-1950s peaking in 1977 CE (Figure 3). This was followed by a decline to the end of the 20th century. Generally, the temporal trends for winter and summer ncV and ncMo concentrations were similar.

\section{Comparison to Source Emission Estimates}

\subsection{Contribution of Fossil Fuel Emissions}

In this section, we compare CDD ice core data with past anthropogenic fossil fuel emissions thought to represent the dominant anthropogenic sources of V and Mo in Europe.

Coal consumption from European countries influencing the CDD site increased from 1880 through the early 1960s CE, followed by a steady decline to the end of the 20th century (Figure 4). The increase was interrupted by a short decline from 1910 to $1920 \mathrm{CE}$ and during the mid-1940s, likely because of low coal use during World War II. No significant correlation was observed between coal consumption and ncV and ncMo ice core concentrations (Table S3), suggesting that coal-burning emissions were not the dominant source of these elements during the 20th century.

The petroleum consumption in western Europe began to increase in the mid-1950s, reaching a peak in the mid-1970s to early 1980s, experiencing a slight decrease in the mid-1980s, while remaining approximately constant to the end of the 20th century (Figure 4). A significant positive correlation was observed between petroleum consumption and ncV and ncMo summer concentrations ( $p<0.0001, n=110)$ (Table S3). We note that ncMo had a slightly lower Pearson's correlation coefficient to petroleum consumption $(r=0.67)$ compared to $\mathrm{ncV}$ ( $r=0.87$ ) (Table S3). This difference may have been because of the earlier increase in ncMo ice concentrations observed in the mid-1900s, potentially suggesting an unaccounted Mo source.

To evaluate further the contribution of fossil-fuel emissions to the budget of V and Mo to the CDD region, we compared the ice core data and emission estimates. Pacyna et al. (1984) estimated anthropogenic fossil fuel emissions of V and Mo in each European country for 1979 CE. Neglecting possible seasonal variations in emissions (e.g., increased emissions from residential heating in the winter), we halved the estimated annual anthropogenic emissions of $\mathrm{V}$ and Mo in each European country to calculate summer emissions assuming that emissions were constant throughout the year. Each country's summer emissions were weighted by their summer emission sensitivity as calculated by FLEXPART for sulfate assuming a similar aerosol 


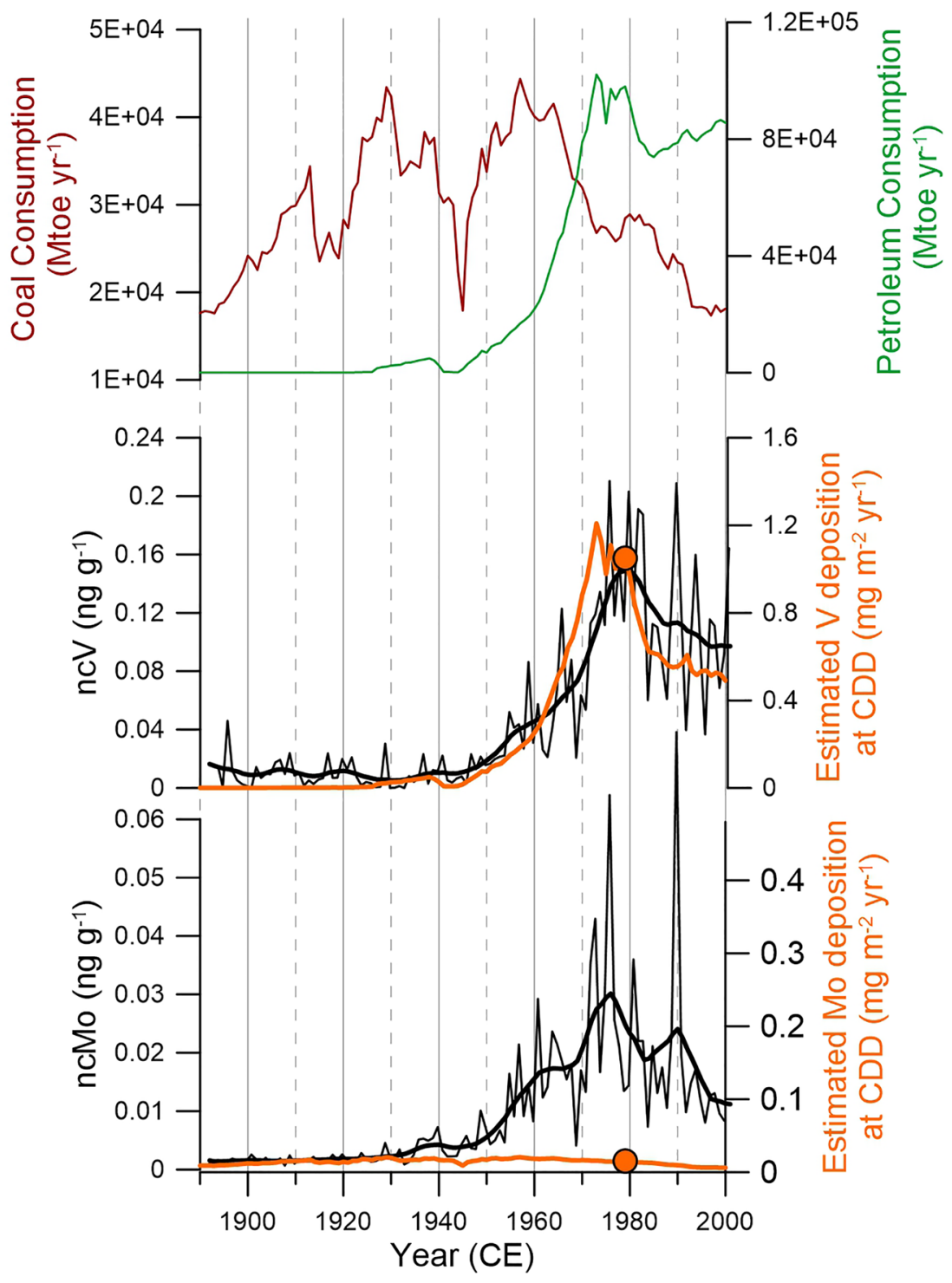

Figure 4. Fossil-fuel consumption, summer ice core trends, and estimated FLEXPART deposition fluxes at Col Du Dome (CDD). Top: Coal (red, left axis) and petroleum (green, right axis) annual consumption estimates from the five surrounding countries scaled by their relative emissions sensitivities estimated by the FLEXPART model for the CDD site. Middle: Ice core summer noncrustal vanadium (ncV) annual mean (thin black line) and ncV summer 7 years single-spectra analysis (SSA) (black thick line) plotted on the left axis. Ice core data are compared to V deposition fluxes (right axis) calculated using FLEXPART simulations and estimated past anthropogenic V emissions (see section 4) over the 20th century (orange line) and in $1979 \mathrm{CE}$ (orange circle symbol). Bottom: Same as middle but for noncrustal molybdenum (ncMo). CE, Common Era.

size distribution and deposition pathway for the two metals (Table S2), resulting in an estimated summer deposition flux of $1.19 \mathrm{mg} \mathrm{m}^{-2} \mathrm{yr}^{-1}$ for $\mathrm{V}$ and $0.0185 \mathrm{mg} \mathrm{m}^{-2} \mathrm{yr}^{-1}$ for Mo for $1979 \mathrm{CE}$ (orange circles, Figure 4). As the orange circles in Figure 4 show, estimated deposition fluxes suggest that the ncV concentration should be $\sim 60$ times the ncMo concentration in 1979 CE. However, the ice core observations at CDD for $1979 \mathrm{CE}$ show that ncV concentrations were only five times greater than ncMo, suggesting a substantial additional source of ncMo (further explored in Section 4.2).

Comparing estimated depositional fluxes of $\mathrm{V}$ and Mo to ice core fluxes is, unfortunately, not straightforward. Typically, the measured ice core concentration would be multiplied by the precipitation rate at the site; however, we only know the annual layer ice thicknesses. The annual layer ice thickness represents 
the net snow accumulation rate including the effect of wind (accumulation or erosion) and does not directly represent past precipitation rates. At Chamonix, located at 1,035 m elevation in the Mt Blanc region, the mean annual precipitation is $\sim 1.25 \mathrm{~m}$ with similar monthly amounts over the course of the year (Climate-Data.org, 2020). We may expect a larger precipitation rate at higher elevations. Assuming a summer (half-year) precipitation rate of $1.5 \mathrm{~m}$ at CDD, a $\mathrm{ncV}$ concentration of $0.15 \mathrm{ng} \mathrm{g}^{-1}$ in 1979 would correspond to a ncV deposition of $0.23 \mathrm{mg} \mathrm{m}^{-2}$ at that time instead of $1.05 \mathrm{mg} \mathrm{m}^{-2}$ as calculated by FLEXPART (orange circle, Figure 4). While this calculation is uncertain, this suggests that the deposition fluxes at CDD as calculated by FLEXPART potentially overestimates the depositional fluxes by a factor of $4-5$. This is likely related to the coarse resolution of the model $(220 \mathrm{~km} \times 155 \mathrm{~km}$ for the CDD grid cell) resulting in the Alpine orography not being well-resolved (mean elevation of the CDD grid cell is 1,166 m). These factors result in an overestimation of the depositional fluxes because a part of the polluted lower atmospheric column is included in the calculation causing an over estimation. Nevertheless, the relative concentration changes in the CDD ice core should reflect past changes in emissions.

We conducted a similar exercise to estimate past deposition fluxes for the entire 20th century (orange line, Figure 4). The deposition estimates for V and Mo during the 20th century were developed using emission sensitivities calculated by FLEXPART, emission factors (EFs) of V and Mo proposed for oil and coal combustion (Pacyna, 1984; Pacyna \& Pacyna, 2001; Pacyna et al., 1984), and the amount of coal and petroleum consumed by European countries.

The main anthropogenic source of V is thought to be oil combustion (Schlesinger et al., 2017). V emissions vary with fuel product, source, and removal efficiencies (Visschedijk et al., 2013). For example, during the 20th century in Europe, petroleum coke was heavily used in oil refineries without emission controls and residual oil was often used in oil refineries as furnace fuel, for fuel in ships, and in electricity generation with zero to more than $90 \% \mathrm{~V}$ removal (Visschedijk et al., 2013). We accounted for a change in V use from oil used in stationary sources to oil used in transportation sources. In $1970 \mathrm{CE}$, we assumed $45 \%$ of total oil consumption was used in stationary sources declining to $20 \%$ of the total oil consumption in the year 2000 CE (Monnoyer-Smith, 2015). For such stationary sources, an EF of $60 \mathrm{~g}$ of $\mathrm{V}$ per tonne of burned oil has been estimated (Pacyna \& Pacyna, 2001), and emission from other sources was estimated to be negligible. Since oil-fired power plants are typically not subject to scrubbing (Pacyna \& Pacyna, 2001; Visschedijk et al., 2013), we assumed this EF value remained valid through the 20th century. Coal burning also emits V, but to a far lesser extent, with only 1,500 tonnes of $\mathrm{V}$ emitted by coal combustion versus 32,900 tonnes of $\mathrm{V}$ emitted from oil combustion in 1979 CE in Europe (Pacyna et al., 1984). V emissions from coal burning were calculated using emission factors reported in Table S4. The decrease of EFs from 1950 to 1995 CE reflects the progressive use of dedusting in coal power plants (Pacyna, 1991; Pacyna \& Pacyna, 2001). We calculated past $\mathrm{V}$ deposition fluxes at CDD from estimated oil and coal consumption in European countries, weighted by the FLEXPART-determined emission sensitivities for each country (Table S2, Figure 4).

For Mo deposition estimates during the 20th century, a similar approach was used. Coal combustion in 1979 CE accounted for 595 tonnes of European Mo emissions, and oil combustion from stationary sources contributed 250 tonnes (Pacyna \& Pacyna, 2001; Pacyna et al., 1984;). The global oil EF was estimated to be $0.3 \mathrm{~g}$ of Mo per tonne of oil burned (Pacyna \& Pacyna, 2001), and past Mo EFs from coal burning are reported in Table $\mathrm{S} 4$.

As shown in Figure 4, the estimated V deposition at CDD during the 20th century parallels the ice core records. The estimated $\mathrm{V}$ deposition increased slowly from $0.04 \mathrm{mg} \mathrm{m}^{-2} \mathrm{yr}^{-1}$ in $1890 \mathrm{CE}$ to $0.11 \mathrm{mg} \mathrm{m}^{-2} \mathrm{yr}^{-1}$ in $1930 \mathrm{CE}$, primarily (>75\%) because of the increase in coal combustion during that time. This increase was difficult to detect in the $\mathrm{ncV}$ ice record because of the variability of ncV concentrations (Figure 4). The large increase in estimated V deposition fluxes from 1950 to 1975 CE was driven by the increase in oil use from stationary sources (energy generation) and generally agreed with the $\mathrm{ncV}$ ice core observations (Figure 4). This rapid increase was followed by a decrease in V deposition by a factor of $\sim 2$ from 1975 to 2000 $\mathrm{CE}$, agreeing with the measured decrease in $\mathrm{ncV}$ ice concentration. The consistency between the estimated deposition fluxes and ice core trend after $1975 \mathrm{CE}$, even though oil consumption remained quasiconstant, strongly supports the decreasing use of oil in stationary sources and the increasing use of oil in transportation. This also suggests, however, that stationary sources continued to be a significant anthropogenic source of $\mathrm{V}$ in Western Europe. 
In contrast to estimated V deposition, the estimated Mo deposition fluxes at CDD from 20th century coal and oil combustion did not agree with the ice core records. The simulated Mo deposition slightly increased from 1890 to $1930 \mathrm{CE}$, mainly because of increased coal burning. From 1930 to $1970 \mathrm{CE}$, the calculated Mo deposition at CDD was relatively unchanged because of stable coal consumption but decreased coal EFs (from use of dedusting in coal power plants) that was compensated by an increase in oil combustion in stationary sources. After $1970 \mathrm{CE}$, coal consumption, coal EFs, and the fraction of oil sourced from stationary sources decreased, resulting in an overall decrease in estimated Mo deposition. While these results suggested that the increase of ncMo concentration observed at CDD between 1890 and $1930 \mathrm{CE}$ could be explained by the increase in coal combustion, the large increase of ncMo after $1950 \mathrm{CE}$ cannot be explained by coal or oil emissions using the assumed EFs.

\subsection{Contribution of Nonfossil Fuel Emissions}

As shown above, relative to the ice core concentrations, little ncMo was sourced from coal combustion after 1950. In addition to a possible underestimation of emission factors of fossil fuel combustion, additional sources of Mo to the CDD site must be considered. Previous studies located close to the Alps have proposed Mo processing and metallurgy as a regional source of Mo. A well-studied peat core from the Jura Mountains, Switzerland exhibits a peak in Mo, V, lead, chromium and nickel in $1967 \mathrm{CE}$, suggesting these are anthropogenically sourced (Krachler \& Shotyk, 2004; Krachler et al., 2003; Shotyk et al., 1998). The authors found that Mo was nearly an order of magnitude greater than the background Mo accumulation rate and attributed the increase to metallurgical sources from central Europe (Krachler \& Shotyk, 2004).

Mo is an important additive in steel production and $~ 79 \%$ of mined Mo is used in metallurgy as an alloying element to increase toughness, strength, stiffness, and corrosion resistance (Cardarelli, 2000). Other applications of Mo include its use as an additive to lubricants, a catalyst, and a pigment (Blossom, 2000; Smedley $\&$ Kinniburgh, 2017). These applications are prepared from mined Mo ore $\left(\mathrm{MoS}_{2}\right)$, which undergoes beneficiation (grinding and floatation) to increase Mo content (Blossom, 1990). The concentrated $\mathrm{MoS}_{2}$ is roasted (oxidized) to obtain molybdenum trioxide $\left(\mathrm{MoO}_{3}\right)$ (Cardarelli, 2000). The $\mathrm{MoO}_{3}$ is then further purified for various needs including in alloys and chemical applications (Blossom, 1990). In addition, ferromolybdenum is produced by the reaction of $\mathrm{MoO}_{3}$ with iron oxide and is used in the production of alloys and cast irons (Blossom, 1990).

To estimate anthropogenic emissions related to the use of Mo ore in Europe, we analyzed Mo consumption statistics (imports minus exports) for the five surrounding countries (France, Italy, Spain, Germany, and Switzerland) from 1956 to 1969 (Institute of Geological Sciences, 1963, 1966, 1971) and from 1970 to 2000 CE (British Geological Survey, 2020). Mo consumption rapidly increased in the late 1960s to a peak in 1976 CE, followed by a decline to the mid-1980s (Figure 5). Mo consumption then increased in the early 1990s to a subsequent decline by the end of the 20th century (Figure 5). These temporal variations in the Mo consumption paralleled the temporal ice core ncMo summer trend. From the Mo consumption peak in 1976 CE to the end of the 20th century, a 2.5-fold decrease is observed, similar to the ncMo decrease observed at the CDD ice core. This is in contrast to global Mo production (U.S. Geological Survey, 2014b) and global steel production (U.S. Geological Survey, 2014a) (Figure 5) that continued to increase through the 20th century.

Most of the Mo imports to Europe were in the form of Mo ore and concentrates, with negligible exports. In Europe, further processing of Mo was required, which would release Mo to the atmosphere. To assess Mo deposition from Mo ore and concentrate, knowledge of Mo EFs during processing are needed. Only one study was found that estimated Mo EF values from Mo ore and concentrate processing (GCA Corporation, 1973). In this study, Mo emissions were shown to occur during all stages of processing, with the greatest emissions during Mo mining, production of ferromolybdenum, the roasting process, as well as steel and alloy production (GCA Corporation, 1973). An overall EF of 5,511 $\mathrm{g}$ of emitted Mo per consumed tonne of ore and concentrates was estimated for the U.S. (GCA Corporation, 1973). Applying this EF value to Mo ore and concentrate consumption in Europe, we estimated the Mo deposition fluxes at the CDD site between 1956 and 2000 CE. While the calculated Mo emissions related to processing ore and concentrates in Europe appeared to be in the same range as those from coal (Figure 5), there is a large uncertainty in the EF value (GCA Corporation, 1973). In addition, the EF value was from the U.S. not Europe. As demonstrated by Legrand et al. (2020), EF values proposed for European emissions of zinc from pig iron, steel, and zinc smelters 


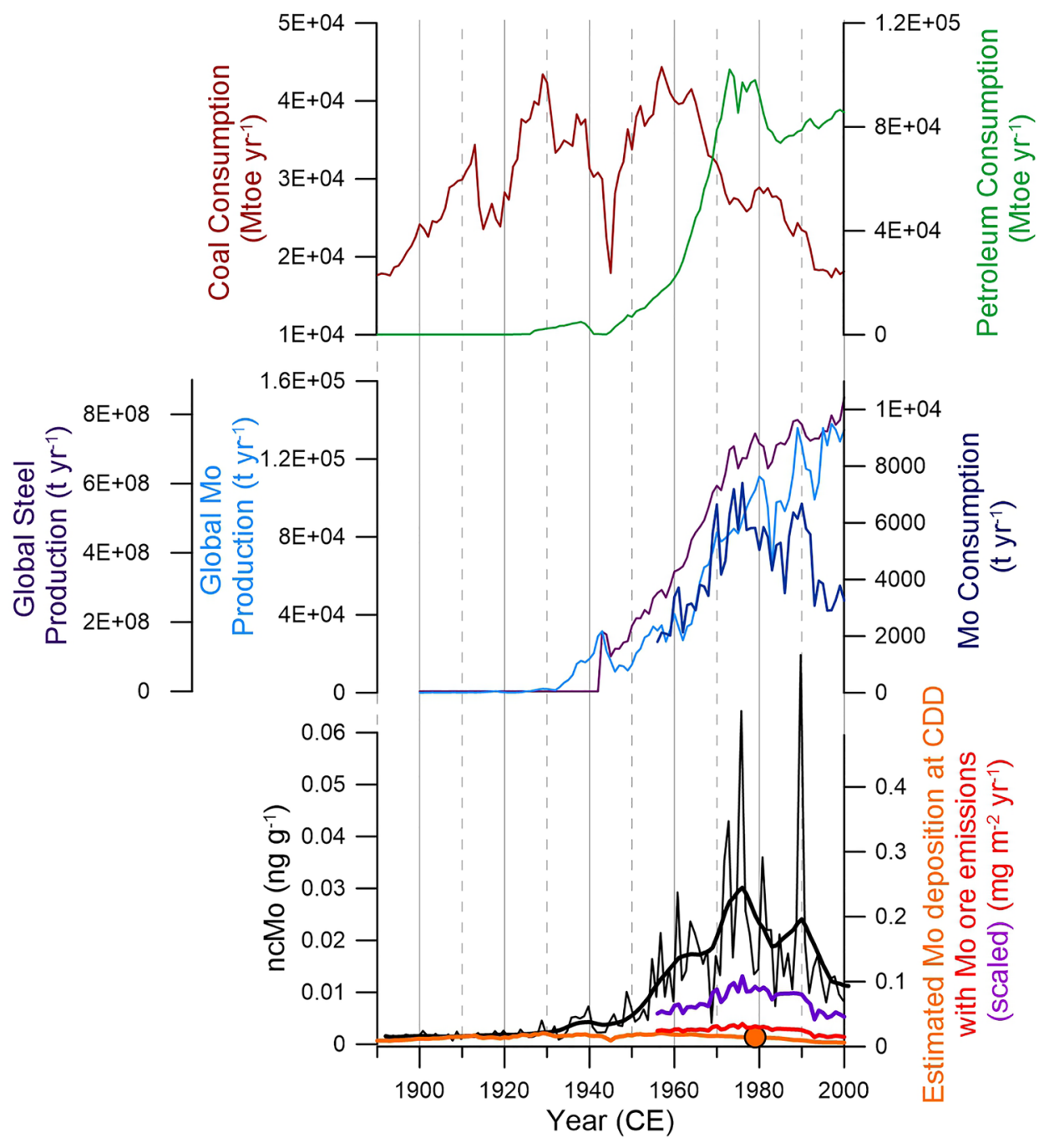

Figure 5. Col du Dome (CDD) summer results compared to deposition fluxes estimates and consumption. Top: same as in the top panel of Figure 4. Middle: Global steel production (purple, U.S. Geological Survey, 2014a), global molybdenum (Mo) production (light blue, U.S. Geological Survey, 2014b), and Mo consumption estimates from the five surrounding countries scaled by their relative emissions sensitivities at the ice core site (blue, right axis) (Institute of Geological Sciences, 1963; 1966; 1971; British Geological Survey, 2020). Bottom: Ice core noncrustal (nc) summer annual mean (black thin line) and noncrustal summer 7 years-SSA (black thick line) are plotted on the left axis. The ncMo deposition fluxes (right axis) are calculated using FLEXPART simulations and estimated past anthropogenic Mo emissions (see Section 4) over the 20th century (orange line) and in 1979 CE (orange circle symbol), considering only fossil-fuel combustion, plotted on the right axis. Red line is the estimated ncMo deposition at the CDD site including emissions from Mo ore and concentrate processing between 1956 and $2000 \mathrm{CE}$, the dark purple line scales the coal burning emission factor by a factor 1.7 , oil combustion emission factor by a factor of 2 , and ore and processing emission factor by a factor of 4, also plotted on the right axis. CE, Common Era.

were underestimated by a factor of three in the 1980s. An even larger underestimation was found for cadmium emissions (a factor of 4.2, Legrand et al., 2020). We calculated the Mo deposition fluxes assuming that the $\mathrm{EF}$ for coal burning were underestimated by a factor of 1.7. The assumption of a larger underestimation of $\mathrm{EF}$ from coal would not agree with the ice core trend prior to 1950, as coal consumption was quite different from the observed ncMo trend in the ice core. We have also assumed an underestimate of the EF from oil combustion by a factor of two. Applying these larger EFs for fossil-fuel combustion and assuming an underestimation of the Mo EF from metallurgy by a factor of 4 (purple line, Figure 5), a reasonably good (within a factor of 2) agreement between the ncMo ice-core trend and calculated past deposition fluxes from 1956 to $2000 \mathrm{CE}$ is observed. For example, a large increase in both the ice core ncMo and the calculated deposition 
fluxes during the late 1950s and 1960s is observed. These results suggest that metallurgy and perhaps also oil burning emissions dominate Mo sources after 1950. However, we note that the Mo deposition estimate does not account for emissions from Mo-containing lubricants in motors, particularly from older cars or Mo emissions from brake linings (Thorpe \& Harrison, 2008; Weckwerth, 2001). A comprehensive study of the emission of Mo from the processing of Mo and the impact of emission control approaches would aid with the further interpretation of the ice core findings.

Based on emission estimates, the $\mathrm{ncV}$ changes in CDD ice are primarily sourced from coal and oil emissions (Figure 4). However, $\mathrm{V}$ is also emitted through the production of ferrovanadium and steel production (Davis and Associates, 1971). Of the V used in metallurgy, 85\% is used in steelmaking, 10\% in titanium alloys, and 5\% for catalysts, ceramics and other uses (Cardarelli, 2000; Davis \& Associates, 1971). V is used in metallurgy as an alloying element to increase strength, hardness, and wear resistance to steels (Cardarelli, 2000). $\mathrm{V}$ is typically mined from $\mathrm{V}$-bearing titaniferous magnetite and roasted and mixed with other reactants to produce Vanadium pentoxide $\left(\mathrm{V}_{2} \mathrm{O}_{5}\right)$ (Cardarelli, 2000). The $\mathrm{V}_{2} \mathrm{O}_{5}$ is then converted to ferrovanadium $(\mathrm{FeV})$ used to produce steel alloys by reducing $\mathrm{V}_{2} \mathrm{O}_{5}$ to $\mathrm{V}$ metal (Cardarelli, 2000). Using production of steel in European countries from 1970 (British Geological Survey, 2020), weighted by the emission sensitivities calculated by FLEXPART, and an EF of $3.3 \mathrm{~kg}$ of V emitted per ktonnes of steel produced (Davis and Associates, 1971), we calculated a total (including fossil fuel and metallurgy) deposition flux of V at CDD of $1.05 \mathrm{mg} \mathrm{m}^{-2} \mathrm{yr}^{-1}$ versus $1.026 \mathrm{mg} \mathrm{m}^{-2} \mathrm{yr}^{-1}$ when considering fossil fuel emissions only. The year 1970 was chosen as steel production in western Europe was nearly at its maximum. Even considering an underestimation of $\mathrm{EF}$ for $\mathrm{V}$ from the metallurgy by a factor of 4 (as done for Mo) the $\mathrm{V}$ emissions from steel production remained insignificant. This supports that $\mathrm{V}$ is primarily sourced from coal and oil.

\section{Conclusion and Outlooks}

Unlike other metals, such as lead, mercury, and cadmium for which past emissions are estimated every 5-10 years (Pacyna et al., 2009), V and Mo anthropogenic sources are not as well documented. Understanding the sources of $\mathrm{V}$ and Mo pollutants is important considering the potential negative health effects at high concentrations (Agency for Toxic Substances and Disease Registry, 2012; Domingo, 1994; Smedley \& Kinniburgh, 2017; World Health Organization, 2003). In the 21st century, V emissions (and hence deposition) may have changed again. The beginning of the 21st century has been characterized by an increase in shipping and port freight activity, accounting in northwestern Europe for 39\% of the V emission in 2005 CE (Visschedijk et al., 2013). Ships typically use heavy oil, and the V content of the heavy oil is proportional to the sulfur content. In $2007 \mathrm{CE}$, regulations were created for the North Sea to reduce the sulfur content of shipping fuel, reducing the atmospheric V concentration in ports (Visschedijk et al., 2013). In addition, the phasing out of residual oil as a fuel in refineries to use natural gas potentially further reduced $\mathrm{V}$ emission in northwestern Europe (Visschedijk et al., 2013). Such policy changes are reflected in V atmospheric concentrations and deposition.

Acknowledgments

The authors thank those who aided with the organization, drilling, processing, and analysis of the ice cores in the field and laboratory. The drilling operations to extract the C10 and CDM ice cores at CDD were supported by the European Community via contract ENV4-CT97 (ALPCLIM) and the

Region Rhône-Alpes. The LEFE-CHAT (CNRS) program provided funding for analysis in France with the support of ADEME. Analysis and interpretation of the CDD ice-core samples also were partially supported by the Desert Research Institute. The authors would also like to thank R. Kreidberg for his editorial advice and the reviewers whose comments greatly improved the manuscript.
In contrast to $\mathrm{V}$, the anthropogenic sources of Mo remain unclear. When compared to the Mo emission estimates from Pacyna and Pacyna (2001), the emissions did not agree with the ice core findings, suggesting an underestimation of Mo emissions from fossil fuel or more likely that there was an additional source of Mo that was not accounted for. We conclude that pre-1950 coal combustion was a dominate Mo source and post-1950 ore processing and metallurgy (and to a lesser extent petroleum) were dominant sources of Mo to the European atmosphere. EF values of these processes, however, are poorly known, and additional studies are necessary to quantify the contribution of ore processing and metallurgy as a Mo source.

\section{Data Availability Statement}

Ice core data used in this study are accessible at https://www.ncdc.noaa.gov/paleo-search/study/31832

\section{References}

Agency for Toxic Substances and Disease Registry (2012). Toxicological profile for vanadium (pp. 1-200). U.S Department of Health and Human Services, Public Health Service. 
Arienzo, M., McConnell, J., Chellman, N., \& Kipfstuhl, S. (2019). Method for correcting continuous ice-core elemental measurements for under-recovery. Environmental Science and Technology, 53, 5887-5894. https://doi.org/10.1021/acs.est.9b00199

Barbante, C., Boutron, C., Moreau, A., Ferrari, C., Van de Velde, K., Cozzi, G., et al. (2002). Seasonal variations in nickel and vanadium in Mont Blanc snow and ice dated from the 1960s and 1990s. Journal of Environmental Monitoring, 4(6), 960-966. https://doi.org/10.1039/ B208142C

Barbante, C., Schwikowski, M., Doring, T., Gaggeler, H., Schotterer, U., Tobler, L., et al. (2004). Historical record of European emissions of heavy metals to the atmosphere since the 1650 s from Alpine snow/ice cores drilled near Monte Rosa. Environmental Science and Technology, 38(15), 4085-4090. https://doi.org/10.1021/es049759r

Blossom, J. (1990). Molybdenum. U.S. Geological Survey minerals yearbook 1990 (pp. 759-771). U.S. Geological Survey.

Blossom, J. (2000). Molybdenum. U.S. Geological Survey minerals yearbook 2000 (pp. 53.1-53.3). U.S. Geological Survey.

Bohleber, P., Erhardt, T., Spaulding, N., Hoffmann, H., Fischer, H., \& Mayewski, P. (2018). Temperature and mineral dust variability recorded in two low-accumulation Alpine ice cores over the last millennium. Climate of the Past, 14, 21-37. https://doi.org/10.5194/ cp-14-21-2018

Bowen, H. (1966). Trace elements in biochemistry (p. 241). New York, NY: Academic Press.

British Geological Survey. (2020). World mineral statistics. https://www2.bgs.ac.uk/mineralsuk/statistics/wms.cfc?method=searchWMS

British Petroleum. (2020). Energy charting tool, App. https://www.bp.com/en/global/corporate/energy-economics/energy-charting-tool-desktop.html

Cardarelli, F. (2000). Materials handbook (p. 1256). Springer.

Climate-Data.org. (2020). Chamonix-Mont-Blanc climat (France). https://fr.climate-data.org/europe/france/rhone-alpes/chamonixmont-blanc-66184/\#climate-table

Davis, W. E., \& Associates (1971). National emissions inventory of sources and emissions of vanadium -1968 (pp. 1-52). Research Triangle Park, NC: Environmental Protection Agency. (Vol. Publication no. APTD-1511).

De Angelis, M., \& Gaudichet, A. (1991). Saharan dust deposition over Mont Blanc (French Alps) during the last 30 years. Tellus Series B: Chemical and Physical Meteorology, 43(1), 61-75. https://doi.org/10.3402/tellusb.v43i1.15246

Domingo, J. L. (1994). Metal-induced developmental toxicity in mammals: A review. Journal of Toxicology and Environmental Health, A Current Issues, 42(2), 123-141. https://doi.org/10.1080/15287399409531868

Doscher, A., Gaggeler, H., Schotterer, U., \& Schwikowski, M. (1995). A 130 years deposition record of sulfate, nitrate and chloride from a high-alpine glacier. Water, Air, and Soil Pollution, 85(2), 603-609. https://doi.org/10.1007/BF00476895

Eckhardt, S., Cassiani, M., Evangeliou, N., Sollum, E., Pisso, I., \& Stohl, A. (2017). Source-receptor matrix calculation for deposited mass with the Lagrangian particle dispersion model FLEXPART v10.2 in backward mode. Geoscientific Model Development, 10, 4605-4618. https://doi.org/10.5194/gmd-10-4605-2017

Eichler, A., Gramlich, G., Kellerhals, T., Tobler, L., Rehren, T., \& Schwikowski, M. (2017). Ice-core evidence of earliest extensive copper metallurgy in the Andes 2700 years ago. Scientific Reports, 7, 1-11. https://doi.org/10.1038/srep41855

Eichler, A., Gramlich, G., Kellerhals, T., Tobler, L., \& Schwikowski, M. (2015). Pb pollution from leaded gasoline in South America in the context of a 2000-year metallurgical history. Science Advances, 1, e1400196. https://doi.org/10.1126/sciadv.1400196

Fagerli, H., Legrand, M., Preunkert, S., Vestreng, V., Simpson, D., \& Cerqueira, M. (2007). Modeling historical long-term trends of sulfate, ammonium, and elemental carbon over Europe: A comparison with ice core records in the Alps. Journal of Geophysical Research, 112, D23S13. https://doi.org/10.1029/2006JD008044

GCA Corporation. (1973). National emissions inventory of sources and emissions of molybdenum (pp. 1-30). Triangle Park, NC: Environmental Protection Agency. (Publication no. EPA-450/3-74-009).

Gogos, A., Wielinski, J., Voegelin, A., von der Kammer, F., \& Kaegi, R. (2020). Quantification of anthropogenic and geogenic Ce in sewage sludge based on Ce oxidation state and rare earth element patterns. Water Research X, 9, 100059. https://doi.org/10.1016/j. wroa.2020.100059

Gustafssona, J. (2019). Vanadium geochemistry in the biogeosphere -speciation, solid-solution interactions, and ecotoxicity. Applied Geochemistry, 102, 1-25. https://doi.org/10.1016/j.apgeochem.2018.12.027

Institute of Geological Sciences. (1963). Statistical summary of the mineral industry: World production, exports and imports 1956-1961. London: H.M. Stationery Office.

Institute of Geological Sciences. (1966). Statistical summary of the mineral industry: World production, exports and imports 1959-1964. London: H.M. Stationery Office.

Institute of Geological Sciences. (1971). Statistical summary of the mineral industry: World production, exports and imports 1964-1969. London: H.M. Stationery Office.

Krachler, M., Mohl, C., Emons, H., \& Shotyk, W. (2003). Atmospheric deposition of V, Cr, and Ni since the late glacial: Effects of climatic cycles, human impacts, and comparison with crustal abundances. Environmental Science and Technology, 37(12), 2658-2667. https:// doi.org/10.1021/es0263083

Krachler, M., \& Shotyk, W. (2004). Natural and anthropogenic enrichments of molybdenum, thorium, and uranium in a complete peat bog profile, Jura Mountains, Switzerland. Journal of Environmental Monitoring, 6(5), 418-426. https://doi.org/10.1021/es0263083

Laloyaux, P., de Boisseson, E., Balmaseda, M., Bidlot, J., Broennimann, S., Buizza, R., et al. (2018). CERA-20C: A Coupled Reanalysis of the Twentieth Century. Journal of Advances in Modeling Earth Systems, 10, 1172-1195. https://doi.org/10.1029/2018MS001273

Legrand, M., McConnell, J., Preunkert, S., Arienzo, M., Chellman, N., Gleason, K., et al. (2018). Alpine ice evidence of a three-fold increase in atmospheric iodine deposition since 1950 in Europe due to increasing oceanic emissions. Proceedings of the National Academy of Sciences of the United States of America, 115, 12136-12141. https://doi.org/10.1073/pnas.1809867115

Legrand, M., McConnell, J. R., Lestel, L., Preunkert, S., Arienzo, M., Chellman, N. J., et al. (2020). Cadmium Pollution from zinc-smelters up to fourfold higher than expected in Western Europe in the 1980s as revealed by alpine ice. Geophysical Research Letters, 47, 1-10. e2020GL087537. https://doi.org/10.1029/2020GL087537

McConnell, J., \& Edwards, R. (2008). Coal burning leaves toxic heavy metal legacy in the Arctic. Proceedings of the National Academy of Sciences of the United States of America, 105, 12140-12144. https://doi.org/10.1073/pnas.0803564105

McConnell, J., Lamorey, G., \& Hutterli, M. (2002). A 250-year high-resolution record of Pb flux and crustal enrichment in central Greenland. Geophysical Research Letters, 29(23), 2130. https://doi.org/10.1029/2002GL016016

McConnell, J., Wilson, A., Stohl, A., Arienzo, M., Chellman, N., Eckhardt, S., et al. (2018). Lead pollution recorded in Greenland ice indicates European emissions tracked plagues, wars, and imperial expansion during antiquity. Proceedings of the National Academy of Sciences of the United States of America, 115, 5726-5731. https://doi.org/10.1073/pnas.1721818115

Mitchell, B. (1978). European historical statistics (pp. 1750-1970). Palgrave Macmillan. 
Monnoyer-Smith, L. (2015). Bilan énergétique de la France pour 2014 (Vol. Juillet 2015): Commissariat General au Developpement DurableService de l'observation et des statistiques (pp. 9-105).

Nriagu, J., \& Pacyna, J. (1988). Quantitative assessment of worldwide contamination of air, water and soils by trace-metals. Nature, 333(6169), 134-139. https://doi.org/10.1038/333134a0

Nriagu, J. O. (1989). Natural Versus Anthropogenic Emissions of Trace Metals to the Atmosphere. In J. M. Pacyna \& B. Ottar(Eds.), Control and fate of atmospheric trace metals (pp. 3-13). Dordrecht: Springer Netherlands.

Pacyna, J. (1984). Estimation of the atmospheric emissions of trace elements from anthropogenic sources in Europe. Atmospheric Environment, 18(1), 41-50. https://doi.org/10.1016/0004-6981(84)90227-0

Pacyna, J. (1991). Emission factors of atmospheric Cd, Pb and Zn for major source categories in Europe in 1950 through 1985 (p. 91 ). Norwegian Institute for Air Research, NILU Report OR 30y.

Pacyna, J., \& Pacyna, E. (2001). An assessment of global and regional emissions of trace metals to the atmosphere from anthropogenic sources worldwide. Environmental Reviews, 9(4), 269-298. http://www.nrcresearchpress.com/doi/abs/10.1139/a01-012\#.WvSpHZdlCM8

Pacyna, J., Pacyna, E., \& Aas, W. (2009). Changes of emissions and atmospheric deposition of mercury, lead, and cadmium. Atmospheric Environment, 43, 117-127. https://doi.org/10.1016/j.atmosenv.2008.09.066

Pacyna, J., Semb, A., \& Hanssen, J. (1984). Emission and long-range transport of trace-elements in Europe. Tellus Series B: Chemical and Physical Meteorology, 36(3), 163-178. https://doi.org/10.3402/tellusb.v36i3.14886

Preunkert, S., \& Legrand, M. (2013). Towards a quasi-complete reconstruction of past atmospheric aerosol load and composition (organic and inorganic) over Europe since 1920 inferred from Alpine ice cores. Climate of the Past, 9, 1403-1416. https://doi.org/10.5194/ cp-9-1403-2013

Preunkert, S., Legrand, M., \& Wagenbach, D. (2001). Sulfate trends in a Col du Dome (French Alps) ice core: A record of anthropogenic sulfate levels in the European midtroposphere over the twentieth century. Journal of Geophysical Research, 106(D23), 31991-32004. https://doi.org/10.1029/2001JD000792

Preunkert, S., Wagenbach, D., \& Legrand, M. (2003). A seasonally resolved alpine ice core record of nitrate: Comparison with anthropogenic inventories and estimation of preindustrial emissions of NO in Europe. Journal of Geophysical Research, 108(D21), 4681. https:// doi.org/10.1029/2003JD003475

Preunkert, S., Wagenbach, D., Legrand, M., \& Vincent, C. (2000). Col du Dome (Mt Blanc Massif, French Alps) suitability for ice-core studies in relation with past atmospheric chemistry over Europe. Tellus Series B: Chemical and Physical Meteorology, 52(3), 993-1012. https://doi.org/10.3402/tellusb.v52i3.17081

Schlesinger, W., Klein, E., \& Vengosh, A. (2017). Global biogeochemical cycle of vanadium. Proceedings of the National Academy of Sciences of the United States of America, 114, E11092-E11100. https://doi.org/10.1073/pnas.1715500114

Schwikowski, M. (2006). Paleoenvironmental reconstruction from Alpine ice cores. PAGES News, 14. https://doi.org/10.22498/pages.14.1.16

Schwikowski, M., Brutsch, S., Gaggeler, H., \& Schotterer, U. (1999). A high-resolution air chemistry record from an Alpine ice core: Fiescherhorn glacier, Swiss Alps. Journal of Geophysical Research, 104(D11), 13709-13719. https://doi.org/10.1029/1998JD100112

Shotyk, W., Weiss, D., Appleby, P., Cheburkin, A., Frei, R., Gloor, M., et al. (1998). History of atmospheric lead deposition since 12,370 C-14 yr BP from a peat bog, Jura Mountains, Switzerland. Science, 281(5383), 1635-1640. https://doi.org/10.1126/science.281.5383.1635

Smedley, P., \& Kinniburgh, D. (2017). Molybdenum in natural waters: A review of occurrence, distributions and controls. Applied Geochemistry, 84, 387-432. https://doi.org/10.1016/j.apgeochem.2017.05.008

Sodemann, H., Palmer, A., Schwierz, C., Schwikowski, M., \& Wernli, H. (2006). The transport history of two Saharan dust events archived in an Alpine ice core. Atmospheric Chemistry and Physics, 6, 667-688. https://doi.org/10.1016/j.apgeochem.2017.05.008

Spath, D. (2000). Proposed action level for vanadium (pp. 1-199). California Environmental Protection Agency. Retrieved from https:// oehha.ca.gov/media/downloads/water/chemicals/nl/palvanadium.pdf

Stohl, A., Forster, C., Frank, A., Seibert, P., \& Wotawa, G. (2005). Technical note: The Lagrangian particle dispersion model FLEXPART version 6.2. Atmospheric Chemistry and Physics, 5, 2461-2474. https://doi.org/10.5194/acp-5-2461-2005

Thorpe, A., \& Harrison, R. M. (2008). Sources and properties of non-exhaust particulate matter from road traffic: a review. The Science of the Total Environment, 400, 270-282. https://doi.org/10.1016/j.scitotenv.2008.06.007

Uglietti, C., Gabrielli, P., Olesik, J., Lutton, A., \& Thompson, L. (2014). Large variability of trace element mass fractions determined by ICP-SFMS in ice core samples from worldwide high altitude glaciers. Applied Geochemistry, 47, 109-121. https://doi.org/10.1016/j. apgeochem.2014.05.019

U.S. Geological Survey. (2014a). Iron and steel statistics. In T. Kelly \& G. Matos (Eds.), Historical statistics for mineral and material commodities in the United States: U.S. Geological Survey data series 140 (pp. 1-3). http://minerals.usgs.gov/minerals/pubs/historical-statistics/

U.S. Geological Survey. (2014b). Molybdenum statistics. In T. Kelly \& G. Matos (Eds.), Historical statistics for mineral and material commodities in the United States: U.S. Geological Survey data series 140 (pp. 1-2). http://minerals.usgs.gov/minerals/pubs/historical-statistics/

Vallelonga, P., Barbante, C., Cozzi, G., Gaspari, V., Candelone, J., Van de Velde, K., et al. (2004). Elemental indicators of natural and anthropogenic aerosol inputs to Law Dome, Antarctica. Annals of Glaciology, Vol 39, 169-174. https://doi.org/10.3189/172756404781814483

Van de Velde, K. (1999). Les neiges et glaces de haute altitude des alpes: Archives de l'histoire de la pollution atmospherique en metaux lourds en Europe au cours des deux derniers siecles (pp. 1-288). Universite Joseph Fourier-Grenoble.

Van de Velde, K., Ferrari, C., Barbante, C., Moret, I., Bellomi, T., Hong, S., \& Boutron, C. (1999). A 200 year record of atmospheric cobalt, chromium, molybdenum, and antimony in high altitude alpine firn and ice. Environmental Science and Technology, 33(20), 3495-3501. https://doi.org/10.1021/es990066y

Visschedijk, A. H. J., Van Der Gon, H. A. C. D., Hulskotte, J. J., \& Quass, U. (2013). Anthropogenic Vanadium emissions to air and ambient air concentrations in North-West Europe. Paper presented at the E3S web of conference, 1, 03004. https://doi.org/10.1051/ e3sconf/20130103004

Weckwerth, G. (2001). Verification of traffic emitted aerosol components in the ambient air of Cologne (Germany). Atmospheric Environment, 35(32), 5525-5536. https://doi.org/10.1016/S1352-2310(01)00234-5

World Health Organization. (2003). Molybdenum in drinking-water: Background document for development of WHO guidelines for drinking-water quality. In Guidelines for drinking-water quality (Vol. 2, 2nd ed., p. 7). Geneva: World Health Organization. https://apps. who.int/iris/handle/10665/75372 